\title{
Is Post-Mortem Organ Donation a Duty Towards Society and Can It Be Justified by Public Interest? Recent Bills to Amend the German Transplantation Law
}

\section{Introduction}

The issue of organ donation by deceased donors is a thorny one in Germany today. The number of donors has remained very low in the recent years. In 2010, there were 1,296 donations after brain death; 2017 saw the lowest rate in the history of German transplantations, down to only 797 donations. The year 2018 brought a slight improvement in the donation rate - up to 955 donations. This number, however, is still by about 340 lower than it was nine years ago. The situation is desperate: in 2018 there were 9,400 patients waiting for an organ ${ }^{2}$. In the last two years, the number of organ donations from deceased donors was the lowest since the introduction of the Transplantation Act (German: Transplantationsgesetz, TPG), in $1997^{3}$. The problem is growing even bigger: according to the statistics of the German Organ Donation Foundation (German: Deutsche Stiftung für Organspende, DSO), there is a consistent decrease from an already low level. In comparison with the rest of Europe, Germany is in the $23^{\text {rd }}$ position with its 10.6 donations per one million inhabitants, a score that is behind Poland, Slovakia or Switzerland, and just before Bulgaria and Romania ${ }^{4}$. Day by day, people are die because they do not receive the right organ on time ${ }^{5}$. Consequently, on 31 October 2018, the German government submitted a bill to improve, first and foremost, the organ donation infrastructure. The act amending the TPG entered into force in April 20196. However,

1 ORCID number: 0000-0002-2212-371X. E-mail: m.laszewska-hellriegel@wpa.uz.zgora.pl

2 Jahresbericht Organspende und Transplantation in Deutschland 2018 [Eng. Annual Report on Organ Donation and Transplantation in Germany 2018], Deutsche Stiftung für Organspende (DSO), https://tinyurl.com/DSOJahresbericht2018, accessed on: 20 June 2020, p. 64.

3 Donation, Removal and Transfer of Organs and Tissues Act of 2007 (German title: Gesetz über die Spende, Entnahme und Übertragung von Organen und Geweben (Transplantationsgesetz)), 4.09.2007 (BGBI. I, S. 2206).

4 Statistics available at: Rate of deceased organ donors including both donation after brain death (DBD) and donation after cardiac death (DCD) in Europe from 2017 to 2018, by country, Statista, https:/www.statista.com/statistics/537908/ deceased-organ-donor-rate-in-europe/, accessed on: 15 August 2019.

5 Jahresbericht Organspende..., pp. 12-15.

6 Second Act Amending the Transplantation Act 2019 (German title: Zweites Gesetz zur Änderung des Transplantationsgesetzes), 22.03.2019 (BGBl. I, S. 352). The aim of the law was to improve the cooperation between the hospitals collecting organs and the hospitals performing transplantations. They were given greater financial support. In addition, 
the Health Minister Jens Spahn decided to go further and introduce the opt-out model into the German transplantation system, in the form of "double objection" (German: doppelte Widerspruchslösung $)^{7}$. A similar system is in place in Poland ${ }^{8}$. The minister's plans were supported by the German Chancellor Angela Merkel, but they failed to get the support of a majority in the CDU/CSU/SPD coalition. Therefore two main competitive bills have been introduced by groups of individual MPs, unrelated to their party affiliation. The German parliament, the Bundestag, considered them in June 2019 and October 2019 but failed to reach a solution. The first bill regulated the opt-out model with the double objection procedure in the Transplantation Act $^{9}$; the second one, which was less radical, gave priority to strengthening the citizens' willingness to donate $\operatorname{organs}^{10}$. The final voting took place on 16 January 2020, when the improved opt-in proposal was adopted by 432 votes in favour, 200 against and 37 abstentions ${ }^{11}$. Interestingly, a survey carried out by ZDF television on the same day showed clear public support for the opt-out model with a large $61 \%$ advantage over $36 \%{ }^{12}$. Both bills provoked a lot of discussion, both in the media and among legal scholars. Let us therefore look at this discussion and analyse the ethical and legal problems with the proposed solutions.

\section{Some facts about organ donation}

The organ transplantation process in Germany needs to be reformed. As mentioned above, 9,400 people are currently awaiting transplantation, while only 955 donors per year decide to donate organs post-mortem ${ }^{13}$. However, these statistics do not reflect the entire picture. In a single case of donation, many organs are usually donated. In practice, most organs - kidneys, pancreas, liver, heart and lungs - can be collected for transplantation at the same time. This means that, ideally, one donor can provide organs for several patients on the waiting list $\mathrm{t}^{14}$. On average, 3.3 organs are removed from a donor every time. This number explains the fact that in 2018, a total of 3,113 organs were removed from 955 donors ${ }^{15}$. From this perspective, the shortfall in the number of donors seems less disastrous.

provisions concerning paperwork were simplified and improved. Another aim of the new law was introducing better care for the families of a deceased donor. Details of the bill available at: Spahn: Die Zahl der Organspenden kann weiter steigen [Eng. Spahn: The number of organ donations can continue to increase], Bundesministerium für Gesundheit, 1.04.2019, https://www.bundesgesundheitsministerium.de/gzso.html, accessed on: 15 August 2019.

7 Known also as the implied assent: in the case of the lack of the declaration of intent from the potential donor it is presumed that he or she agreed to donate his or her organs.

8 Article 5(1) of the Act on the Collection, Storage and Transplantation of Cells, Tissues and Organs (Polish title: Ustawa z 1.07.2005 r. o pobieraniu, przechowywaniu i przeszczepianiu komórek, tkanek i narządów, tekst jedn.: Dz. U. z 2019 r. poz. 1405), hereinafter: "Polish Transplantation Law".

9 Draft Law on the Regulation of the Double Objection in the Transplantation Law 2019 (German title: Entwurf eines Gesetzes zur Regelung der doppelten Widerspruchslösung im Transplantationsgesetz), Bundestags-Drucksache 19/11096, 25.06.2019.

10 Draft Law to Strengthen the Willingness to Take Decisions to Donate Organs 2019 (German title: Entwurf eines Gesetzes zur Stärkung der Entscheidungsbereitschaft bei der Organspende), Bundestags-Drucksache 19/11087, 25.06.2019.

11 Deutscher Bundestag Stenografischer Bericht, 140. Sitzung, Plenarprotokoll 19/140 [Eng. Minutes of German Bundestag, 140 th Session, Plenary Protocol 19/140], http://dipbt.bundestag.de/dip21/btp/19/19140.pdf, accessed on: 22 January 2020.

12 Mehrheit für Widerspruchslösung bei Organspende [Eng. Majority in Favour of Opt-out Model for Organ Donation], ZDF, 16.01.2020, https://www.zdf.de/politik/politbarometer/200116-gruene-erfolgreich-richtung-mitte-100.html, accessed on: 22 January 2020.

13 Jahresbericht Organspende..., p. 64.

14 Usually, kidney transplantation is carried out together with a pancreatic transplant from the same donor. See: Statistiken zur Organtransplantation [Eng. Organ Donation Statistics], DSO, https://www.dso.de/organspende/statistiken-berichte/organtransplantation, accessed on: 18 August 2019.

15 Jahresbericht Organspende..., p. 64. 


\section{Legislation and practice to date}

There are two basic models of consenting to organ donation: an opt-in model (a consent model) and an opt-out model (an objection model). Under the opt-in model, donation is only possible with the consent of the deceased. This model is used in some European countries ${ }^{16}$ as well as in the USA ${ }^{17}$. Contrary to the opt-in model, in the opt-out model organs can be removed if there is no information about the donor's objection. This model is applicable in most European countries ${ }^{18}$. The distinction between the consent and objection models frequently leads to misunderstandings. These concepts often raise doubts and fears that in the absence of a clear declaration, such as a donor document, in the opt-in model there may be no consent for a donation, and in the opt-out model the absence of objection will always result in a donation. However, this is usually not the case, neither in practice nor in law.

The German law currently uses the so-called decision-making solution, or Entscheidungslösung ${ }^{19}$. This solution is a model of obtaining consent. Its name may be explained by the fact that the donor's decision should exist before the process starts. According to $\S 2$ (1a) of the TPG, health insurance companies have a duty to send citizens a donor card along with their electronic insurance card ${ }^{20}$. On the so-called donor card, each insured person can decide whether or not to donate his or her organs. In principle, according to § 3 (1) (1) of the TPG, an organ can only be extracted if there is clear consent. In accordance with $\S 4$ of the TPG, in the absence of written consent or written objection, a doctor looking after the potential donor turns to their closest family. In such a case, the question to the relatives is asked in two phases. The first phase asks whether the potential donor during his or her life has made a statement about organ donation. The lack of such declaration does not mean that the donation cannot take place. The doctor then proceeds to the second phase, asking whether the relatives consent to organ extraction - i.e. the relatives decide on the donation. In their decision, the relatives of the deceased donor should respect his or her presumed will. The question about consent is asked in four steps: 1) whether there was a written statement from the brain-death donor; 2) whether there was a statement from the donor made to the relatives; 3 ) what was the presumed will of the potential donor; 4) what is the final decision of the relatives. Only after these four steps can organs be removed, provided that the relatives have given their consent.

In practice, a potential donor after brain death is kept in a stable state through appropriate stabilizing drugs. This is a kind of an intensive therapy applied in order to protect the organs ${ }^{21}$. During this time the physician talks to the family of the potential donor ${ }^{22}$.

16 For instance in: Denmark, Germany, Ireland, Lithuania, Holland, Romania, and Cyprus. Transplant-Jahresbericht 2018 [Eng. Annual Report on Transplantation], Österreichisches Bundesinstitut für Gesundheitswesen, p. 10, https:// transplant.goeg.at/Jahresbericht2018, accessed on: 17 August 2019.

17 R.H. Thaler, C.R. Sunstein, Nudge: Improving Decisions About Health, Wealth and Happiness, New Haven 2008 , p. 4.

18 For instance in: Austria, Belgium, Bulgaria, Croatia, Czech Republic, Finland, France, Greece, Hungary, Malta, Norway, Latvia, Luxembourg, Poland, Portugal, Slovakia, Slovenia, and Spain. Transplant-Jahresbericht 2018, p. 10.

19 See: Draft Law on the Regulation of the Decision-Making Solution in the Transplantation Act (German title: Entwurf eines Gesetzes zur Regelung der Entscheidungslösung im Transplantationsgesetz), Bundestags-Drucksache 17/9030, 21 March 2012.

20 Here you can see the influence of "nudging”. Richard H. Thaler and Cass R. Sunsten propose introducing mandatory decision about donation, at the time of application for a driving license. R.H. Thaler, C.R. Sunstein, Nudge: Improving..., p. 180.

21 Leitfaden für die Organspende [Eng. Guide to Organ Donation], DSO, chapter 6, https://www.dso.de/aploads/tx.. dsodl/Leitfaden.pdf, accessed on: 15 August 2019.

22 Jahresbericht Organspende..., p. 64. 
This conversation is an indispensable part of the organ donation procedure. Part of the interview is held in the presence of the coordinator of the DSO. This procedure is internationally recognized as "best practice"; the presence of a well-trained transplant donor coordinator increases the chances of obtaining consent for organ donation ${ }^{23}$. The position of the relatives during such a conversation is extremely difficult. Most decisions about organ donation are made after a sudden, unexpected death ${ }^{24}$. For an ordinary person, the required intensive therapy that protects the organs after brain death does not differ much from the intensive therapy before brain death. Respiratory ventilation creates the impression that the person who has already been diagnosed with brain death is still alive; their vital signs are preserved and their temperature is stable ${ }^{25}$. Doubts often emerge as to whether the doctor was not mistaken in pronouncing brain death. In 2018, in Germany, this kind of decision was made in 1,416 cases, out of which 995 were positive and resulted in organ donation, whereas 421 requests were refused ${ }^{26}$.

\section{The proposal for a "double objection" solution: the opt-out principle}

In order to increase the number of transplants carried out, one group of MPs drafted a proposal to introduce an objection (opt-out) model, mentioned above. In this case, it is a double objection model, i.e. the so-called soft opt-out mode ${ }^{27}$. According to this model, anyone can, during their lifetime, object to donating an organ either by making a relevant entry in the register of objections or by making a written statement. However, if there is no registered objection or no written form of such an objection, the attending physician is obliged to ask relatives whether they know about the deceased's objection to the removal of his/her organs ${ }^{28}$. So it is only the will of the potential donor that matters; as such, the term "double objection" is misleading. The only factor in the decision-making process should be the potential donor's will, not the will of their relatives. In practice, though, it is easy to imagine cases in which the will of the potential donor is replaced by the will of his or her relatives ${ }^{29}$. In the case of such a regulation, not much would change in practice. However, a theoretical approach to the problem shows that from the ethical perspective, our perception of the body has changed. The burden of proof has been shifted in line with the in dubio pro quaestus principle - in case of doubt to be resolved in favour of organ donation. It is one thing to consent altruistically to the organ donation and another to regard silence as consent to the organ donation. It is worth noting that nowadays our individual rights are strictly protected by law ${ }^{30}$.

23 L.A. Siminoff, N. Gordon, J. Hewlett, R.M. Arnold, Factors influencing families' consent for donation of solid organs for transplantation, "Journal of American Medical Association” 2001/1, p. 71.

24 As the reason for consenting to the removal of an organ 197 relatives mentioned "giving meaning to the sudden death of a loved one". Jahresbericht Organspende..., p. 58.

25 C. Mitre, Diagnosing "Brain Death" in Intensive Care, "Journal of Critical Care Medicine" 2017/3, pp. 128-130.

26 Jahresbericht Organspende..., p. 57.

27 Unlike a hard opt-out model, which is used e.g. in Poland. Pursuant to Article 5(1) of Polish Transplantation Law an organ is collected if the deceased did not express any objection. An objection may be expressed in accordance with Article 6(1)(1)-(3) of the law by entering the objection in the register, a written statement signed by hand or an oral statement submitted in the presence of two witnesses and confirmed by them in writing.

$28 \S 4(1)$ of Draft Law on the Regulation of the Double Objection in the Transplantation Law 2019.

29 Taking account of the relatives' will could be justified e.g. by the respect for the feelings of the mourning family members.

30 For example: Regulation (EU) 2016/679 of the European Parliament and of the Council of 27 April 2016 on the protection of natural persons with regard to the processing of personal data and on the free movement of such data, and repealing Directive 95/46/EC (General Data Protection Regulation). 
According to law, these rights should only be waived with our consent. However, as far as our organs are concerned, in the name of public interest, our consent is implied in the event of silence. The institution of implied consent is of marginal importance in ${ } \mathrm{w}^{31}$. In this case, I ask whether an opt-out model can be applied in the name of public interest. Does this model not restrict our rights, and if it does, is this restriction justified?

\subsection{Limitation of the right to self-determination. Articles 1(1) and 2(1) of the German Constitution}

In international medical ethics, the right to self-determination is often understood as the autonomy of the patient; in our case, it is the autonomy of the donor. The right to self-determination has become the central idea of medical ethics ${ }^{32}$. It is a mark of humanity, a fundamental and natural right that belongs to every human being. It even applies to mentally ill people, who due to a lack of legal capacity cannot exercise their free will to the same extent as others, as well as to people with damaged brain functions. The autonomy of such people will be based on the fact that they have the right not to be merely an object in the decision-making process. They have the right to be treated as having a right to a decision that cannot be articulated. Therefore, the legitimate interests of such a person will be represented ${ }^{33}$. In medicine, the right to self-determination includes the patient's competence to make decisions about the treatment to be performed, as well as the right to donate organs ${ }^{34}$. According to the ethical concept of self-determination, people have a strong need to control their inner integrity. This statement is also in compliance with the Catholic Church doctrine. As a limitation of one's self determination, the Catholic catechism mentions disability and death: "It is morally unacceptable to directly cause permanent disability or death to one human being, even if this would prolong the lives of others" ${ }^{35}$. In the present case, however, we are talking about a donation after death. The opt-out solution is not entirely a restriction on the right to self-determination, as a potential donor has the opportunity to make a decision during his or her lifetime. In most cases, however, this possibility will again be merely theoretical. What citizen, especially young people (whose organs are the most sought after), thinks about death and enters objections in the register? This is a small number of people, because the majority of us try not to deliberate on death and for young people it is a very distant event. The opt-out model therefore takes advantage of this situation, a situation of some ignorance or indifference, and limits the right to self-determination by making a decision for the potential donor. Peter Dabrok, previous chairman of the

31 See e.g.: Article 362 of the German Commercial Code (German title: Handelgesetzbuch), 10.05.1897 (RGBl. I, S. 219). See also: J. Wróbel, Zgoda domniemana w polskiej ustawie transplantacyjnej. Watpliwości $i$ obawy natury etycznej [Eng. The Implied Consent in the Polish Transplantation Act. Ethical Concerns and Doubts], in: A. Marcol (ed.), Etyczne aspekty transplantacji narządów [Eng. Ethical Aspects of Organ Transplantation], Opole 1996, p. 36; P.G. Nowak, Problemy etyczne transplantologii. Perspektywa niedoboru narządów do przeszczepów [Eng. Ethical Problems of Transplantology. The Prospect of a Shortage of Organs for Transplantation], "Diametros" 2014/42, pp. 150-177. See also: section 4.3 below.

32 M. Nowacka, Filozoficzne podstawy autonomii zasady autonomii pacjenta [Eng. Philosophical Foundations of the Patient's Autonomy Principle], "Problemy Higieny i Epidemiologii" 2008/3, p. 326.

33 A. Zawiślak, Problemy autonomii osób dorostych z niepetnosprawnościa intelektualna [Eng. Problems of Autonomy of Adults with Intellectual Disabilities], "Rocznik Naukowy Kujawsko-Pomorskiej Szkoły Wyższej w Bydgoszczy. Transdyscyplinarne Studia o Kulturze (i) Edukacji” 2008/3, pp. 41-46.

34 M. Nowacka, Etyka transplantacji [Eng. Ethics of Transplantation], in: J. Różyńska, W. Chańska (eds.), Bioetyka [Eng. Bioethics], Warszawa 2013, p. 224.

35 The Catechism of the Catholic Church, No. 2296. 
German Ethics Council (German: Deutscher Ethikrat) has called the opt-out model "the obligation to donate the organ with the possibility of opt-out"36.

The German Constitution ${ }^{37}$ (German: Grundgesetz, GG), in Article 2(1) in conjunction with Article 1(1), protects fundamental rights by giving their holders the right to make decisions on their own behalf. In a negative sense, it also includes the principle of freedom not to have to deal with certain questions and decisions in order to preserve the right to self-determination ${ }^{38}$. These decisions include, in particular, decisions on medical treatment and, where appropriate, decisions on post-mortem procedures. The opt-out model therefore restricts the right to self-determination by taking a decision for the potential donor unless the donor objects. In theory there is a clear difference between a duty to make an informed decision and a duty to donate. The restriction of the fundamental right to self-determination by imposing an obligation to make a decision is definitely less severe than it would be in the case of the duty to donate. In view of the dramatic fate of patients on the waiting list and limited possibilities of alternative therapies, an obligation to make a decision is considered a comparatively less severe burden. In reality, though, the difference between both forms of obligations might be less clear: lack of action will in many cases result in an actual duty to donate and in removal of organs. Thus what law frames as a duty to decide might in reality be a duty to donate - and should be treated accordingly. Whether the restriction of the right to self-determination may therefore be justified by public interest and by the interest of the organ recipients needs further analysis (see: section 4.4).

\subsection{The right to life and physical integrity. Article 2(2) GG}

The Grundgesetz in the first sentence of Article 2(2) establishes the right to life and physical integrity. A person protected by this principle may decide autonomously about his or her integrity. This right derives from the right to self-determination enshrined in Article 2(1) $\mathrm{GG}^{39}$. The right to bodily integrity protects against physical health violations within the meaning of "biological and physiological" 40 . It protects mental health as well, if the violation leads to pain or a comparable effect ${ }^{41}$. The fundamental question is whether a person after brain death is protected by Article 2(2) GG. Constitutional protection ends with death ${ }^{42}$. Currently, in medicine, the moment of cardiac arrest and

36 Speech by MP Karin Maag at the $106^{\text {th }}$ Session of the Bundestag on 26 June 2019, Minutes from the $106^{\text {th }}$ Session of the $19^{\text {th }}$ Term of Bundestag, 26.06.2019, p. 13010, http://dipbt.bundestag.de/doc/btp/19/19106.pdf, accessed on: 27 June 2020.

37 Basic Law for the Federal Republic of Germany (German title: Grundgesetz für die Bundesrepublik Deutschland), 23.05.1949 (BGBl., S. 1).

38 H. Sengler, A. Schmidt, Verfassungsrechtliche Fragen einer gesetzlichen Regelung des Transplantationsrechts [Eng. Constitutional Issues of a Legal Regulation of Transplantation Law], "Die Öffentliche Verwaltung (DÖV)” 1997, pp. 718-725.

39 Judgment of the German Federal Constitutional Court (German: Bundesverfassungsgericht) of 15 February 2006 (1 BvR 357/05), Amtliche Sammlung - Die Entscheidungen des Bundesverfassungsgerichts von (BVerfGE) 115, pp. 118, 139ff.

40 Judgment of the German Federal Constitutional Court of 14 January 1981 (1 BvR 612/72), BVerfGE 56, pp. 54, 73.

41 P. Jarass, Art. 2, in: P. Bodo (ed.), Grundgesetz für die Bundesrepublik [Eng. Basic Law for the Federal Republic of Germany], 11 ${ }^{\text {th }}$ ed., München 2011, No. 33-38, Beck Online/el.

42 P. Jarass, Art. 2, No. 81. See also: Judgment of the German Federal Constitutional Court of 15 February 2006 (1 BvR 357/05), pp. 118, 139. Cf. K.A. Schachtschneider, D. Siebold, Die „erweiterte Zustimmungslösung“ des Transplantationsgesetzes im Konflikt mit dem Grundgesetz [Eng. The "Extended Consent Solution" of the Transplantation Act in Conflict with the Basic Law], "Die Öffentliche Verwaltung (DÖV)" 2000, pp. 129-137. The authors do not rule out the possibility that a person with brain death has no right to life. Also: W. Höfling, Art. 1, in: M. Sachs (ed.), Grundgesetz, Kommentar [Eng. Basic Law: Commentary], $5^{\text {th }}$ ed., München 2009, No. 63, Beck Online/el. (with further references), where a person with brain death is treated as a "person dying but not yet dead". 
circulatory arrest has been rejected as the moment of death in favour of the so-called brain death. Brain death implies an irreversible lack of brain functions including the ability to feel, think, and make decisions, while still maintaining vital bodily functions ${ }^{43}$. Opponents of the brain death definition see it only as a criterion established for the purpose of organ donation ${ }^{44}$. This raises the question of possible abuses during what is referred to as the process of dying (German: Sterbeprozess) and the problem of trust in the healthcare system. Some experts argue the number of donations is likely to increase if confidence in the healthcare system is restored ${ }^{45}$. In view of the crucial importance of the fundamental right to life, and in view of the fact that it is only with this right that we can exercise other fundamental rights, we should be guided by the in dubio pro vita principle. This principle would extend the right to life also to a person diagnosed with brain death ${ }^{46}$. In such a scenario - even in the case of having secured consent of the person with brain death - every removal of organs would imply murder ${ }^{47}$. Nevertheless, we must remember that a person diagnosed with brain death is still dependent on a ventilator to breathe. When the equipment is switched off, the vital signs should stop due to brain inactivity. The brain death criteria are based on the signs of imminent death ${ }^{48}$. The legal interpretation is that there is no time between life and death and therefore the dying person is treated as a living person ${ }^{49}$. However, a person diagnosed with brain death is recognized by law as a dead person because all their vital functions are received by means of technological apparatus and there is no longer any hope of improvement. Therefore, such a person will not be protected by the first sentence of Article 2(2) $\mathrm{GG}^{50}$.

43 Richtlinien zur Feststellung des Hirntod. Wissenschaftlicher Beirat der Bundesärztekammer [Eng. Guidelines for the Diagnosis of Brain Death. Scientific Council of the Federal Medical Chamber in Germany], "Deutsches Ärzteblatt" 1998/95, pp. 1861-1868.

44 W. Höfling, Art. 1, No. 63; W. Höfling, Hirntodkonzeption und Transplantationsgesetzgebung [Eng. Brain Death Conception and Transplantation Legislation], "MedR Schriftenreihe Medizinrecht" 1996, pp. 6-8; W. Höfling, Um Leben und Tod: Transplantationsgesetzgebung und Grundrecht auf Leben [Eng. About Life and Death: Transplant Legislation and Fundamental Right to Life], "JuristenZeitung” 1995/1, pp. 26-33; K.A. Schachtschneider, D. Siebold, Die ,erweiterte Zustimmungslösung”..., pp. 129-137; S. Rixen, Lebensschutz am Lebensende. Das Grundrecht auf Leben und die Hirntodkonzeption. Zugleich ein Beitrag zur Autonomie rechtlicher Begriffsbildung [Eng. Protection of Life at Its End. The Fundamental Right to Life and the Conception of Brain Death. At the Same Time a Contribution to the Autonomy of Legal Terminology], Berlin 1999, p. 277.

45 Speech by MP Katrin Vogler at the $106^{\text {th }}$ Session of the Bundestag on 26 June 2019, Minutes from the $106^{\text {th }}$ Session of the $19^{\text {th }}$ Term of Bundestag 26.06.2019, p. 13017, http://dipbt.bundestag.de/doc/btp/19/19106.pdf, accessed on: 27 June 2020.

46 R. Alexy, Theorie der Grundrechte [Eng. Theory of Fundamental Rights] $3^{\text {rd }}$ ed., Frankfurt am Main 1996, pp. 278-299; S. Rixen, Lebensschutz..., p. 310; W. Kluth, Die Hirntodkonzeption: Medizinisch-anthropologische Begründung, verfassungsrechtliche Würdigung, Bedeutung für den vorgeburtlichen Würdeschutz [Eng. The Concept of Brain Death: Medical-Anthropological Justification, Constitutional Appreciation, Significance for Prenatal Dignity Protection], "Zeitschrift für Lebensrecht" 1996/1, p. 9.

47 W. Heun, Der Hirntod als Kriterium des Todes des Menschen - Verfassungsrechtliche Grundlagen und Konsequenzen [Eng. The Brain Death as a Criterion of the Death of Humans - Constitutional Bases and Consequences], "JuristenZeitung" 1996/5, p. 218; E. Wagner, L. Brocker, Hirntodkriterium und Lebensgrundrecht [Eng. Criterion of Brain Death and Fundamental Right to Life], "Zeitschrift für Rechtspolitik" 1996/6, pp. 226, $228 \mathrm{ff}$.

48 H. Angstwurm, Der Hirntod als sicheres Todeszeichen des Menschen und als eine Voraussetzung der Organentnahme [Eng. Brain Death as a Certain Sign of Human Death and as a Prerequisite for Organ Removal], in: H.J. Firnkorn (ed.), Hirntod als Todeskriterium [Eng. Brain Death as a Death Criterion], Stuttgart 2000, p. 7; I. Klinge, Todesbegriff, Totenschutz und Verfassung. Der Tod in der Rechtsordnung unter besonderer Berücksichtigung der verfassungsrechtlichen Dimension [Eng. Concept of Death, Protection of the Dead and Constitution. Death in the Legal System with Special Consideration of the Constitutional Dimension], Baden-Baden 1996, pp. 166-182.

49 W. Höfling, Hirntodkonzeption ..., p. 7.

50 W. Höfling, Hirntodkonzeption ..., p. 8. 


\subsection{Does silence mean consent?}

The remaining question is whether it is compatible with the right to self-determination to consider silence as consent in the absence of objections? In this case, there are two seemingly contradictory theories. The first rule, deriving from canon law, says: Qui tacet, consentire videtur. The second rule, which usually applies in civil law, treats silence as lack of declaration if there are no special circumstances that could be treated as an implied declaration ${ }^{51}$.

Qui tacet, consentire videtur, was adopted as a legal rule in Liber Sextus to be supplemented by ubi loqui potuit ac debuit. Here silence means consent if an objection could and should have been made ${ }^{52}$. The opt-out model it based on this reasoning. It means that the potential donor agrees to donate by keeping silent, because the matter is important enough that he or she should have expressed his/her will.

According to the second principle, silence is to be interpreted as an objection if there is an explicit expectation of a statement ${ }^{53}$. If we apply this principle to the opt-out model, it is obvious that, in the absence of an objection, consent to organ donation is not implied in case of silence. If we look at the second alternative, we can see that when it is applied here, the objection statement would be superfluous, because the very fact of silence expresses opposition ${ }^{54}$.

In my opinion, the principle of presumed consent contained in the-opt out model does not allow us to ensure that the posthumous organ donation actually corresponds to the will of the deceased and therefore we cannot be sure that their right to self-determination has not been violated ${ }^{55}$.

\subsection{Potential justifications for making organ donation compulsory}

Can an opt-out model that introduces a form of compulsory donation in some way be legally justified as an obligation to the society based on the principle of public interest or another principle? In order to answer this question, it is necessary to look at the relevant criteria that support this justification.

Firstly, according to Otto Luchterhandt's argumentation ${ }^{56}$, obligations to the society can be established if they are indispensable and of particular importance to it:

51 See: H. Heinrichs, $\S 148$, in: O. Palandt (ed.), Bürgerliches Gesetzbuch [Eng. Civil Code], 70 ${ }^{\text {th }}$ ed., München 2011, No. 8, Beck Online/el.

52 D. Liebs, Lateinische Rechtsregeln und Rechtssprichwörter [Eng. Latin Legal Rules and Proverbs], $7^{\text {th }}$ ed., München 2007, p. 195ff.

53 A. Wacke, Keine Antwort ist auch eine Antwort. Qui tacet, consentire videtur, ubi loqui potuit ac debuit [Eng. No Answer Is Also an Answer. Qui tacet, consentire videtur, ubi loqui potuit ac debuit], "Juristische Arbeittsblätter" 1982, p. 184. This principle was first introduced by Johann Friedrich Eisenhart in a compilation published by him in 1758 . J.F. Eisenhart, Grundsätze der deutschen Rechte in Sprichwörtern [Eng. Basics of German Law in Proverbs], Leipzig 1792.

${ }^{54}$ See: F. Kelle, Eine verfassungsrechtliche Untersuchung zur Begründbarkeit einer Organspendepflicht und zur Vereinbarkeit von Menschenwürde und Widerspruchslösung unter Berücksichtigung ethischer und medizinischer Aspekte [Eng. A Constitutional Investigation on the Justifiability of an Organ Donation Obligation and on the Compatibility of Human Dignity and the Solution of Objections, Taking into Account Ethical and Medical Aspects], in: H. Lilie (ed.), Schriftenreihe Medizin-Ethik-Recht [Eng. Medicine-Ethics-Law Series], Halle 2011, pp. 156-159.

55 C. Starck, Art. 1 (1), in: H. v. Mangoldt, F. Klein, C. Starck (eds.), Kommentar zum Grundgesetz [Eng. Basic Law. A Commentary], Vol. 1, $6^{\text {th }}$ ed., München 2010, No. 22, 95, Beck Online/el.; K.A. Schachtschneider, D. Siebold, Die „erweiterte Zustimmungslösung”..., p. 134; W. Heun, Der Hirntod..., pp. 213, 217.

56 O. Luchterhandt, Grundpflichten als Verfassungsproblem in Deutschland. Geschichtliche Entwicklung und Grundpflichten unter dem Grundgesetz [Eng. Basic Duties as a Constitutional Problem in Germany. Historical Development and Basic Obligations under the Basic Law], Berlin 1988, pp. 579-588. 
"if obligations for the constitutional existence of the community are indispensable and essential" ${ }^{57}$, and if they can be considered particularly close to public affairs and the functioning of the society ${ }^{58}$. The provision of a healthcare system is one of the basic duties of a state. The state has a duty to protect the life and health of the patients on the waiting list. However, the obligation to provide a sufficient number of organs cannot be derived from this state responsibility, nor does the functioning of the society depend on the number of organs provided. It is possible to obtain organs in other ways without imposing an obligation to donate them on the citizens.

Secondly, a relevant reference in the text of the German Constitution is considered to be a necessary condition for imposing an obligation ${ }^{59}$. At the moment there is no explicit obligation to donate organs in the German Constitution. However, there is a possibility that such an obligation can be derived from other constitutional provisions. If we follow the principle that the state, by virtue of its sovereignty, can impose obligations, it is imaginable that such an obligation to donate organs could be postulated. In this case, we need to look at the limits of the state's ability to impose obligations onto its citizens. Those limits derive both from the constitution and from the form of the state. Through Grundgesetz, a liberal state was created that respects the freedom of the individual. This does not mean that the citizens do not have any obligations, but it is evident from the constitutional principles that imposing them is only possible to a limited extent ${ }^{60}$. The opt-out model implies a far-reaching obligation to donate organs after death. It is doubtful if this would not cross the constitutional boundaries.

Thirdly, at first glance, there is an obligation of solidarity between the individual and the society in which he or she lives and to which he or she is attached, as well as public interest in sufficient supply of organs for transplants. The existence of a shortage of organs in relation to those on the waiting list and the consequences of that shortage may in principle justify applying the principle of solidarity and public interest ${ }^{61}$. However, only a moral and ethical appeal can be inferred from this duty, and not a legal obliga$\operatorname{tion}^{62}$. Moreover, it should be remembered that the model of welfare state primarily obliges the state to act, not its citizens. Justifying such an obligations on the basis of a general clause of public interest goes too far. Although the citizen must pay social security contributions and taxes, the sacrifice of body parts, and thus the sacrifice of bodily integrity, cannot be expected for the sake of public interest. The case looks different in military service: here, the obligation to sacrifice life, the highest good one possesses, can be justified by protection of the country's sovereignty and the existence of the society which will be covered by the definition of public interest ${ }^{63}$.

57 German: ,für den verfassungsmäßigen Bestand des Gemeinwesens schlechterdings unverzichtbar, unentbehrlich sind”. O. Luchterhandt, Grundpflichten..., pp. 579-588.

58 See further: O. Luchterhandt, Grundpflichten..., pp. 579-588.

59 O. Luchterhandt, Grundpflichten..., pp. 580.

60 See: J. Isensee, Die verdrängten Grundpflichten des Bürgers [Eng. The Suppressed Basic Duties of the Citizen], "Die Öffentliche Verwaltung (DÖV)" 1982, pp. 609-618; D. Merten, Grundpflichten im Verfassungssystem der Bundesrepublik Deutschland [Eng. Basic Obligations in the Constitutional System of the Federal Republic of Germany], "Bayerische Verwaltungsblätter" 1978 , pp. 554-559.

${ }_{61}$ H.C. Kühn, Das neue deutsche Transplantationsgeset [Eng. The New German Transplantation Law], "MedR Schriftenreihe Medizinrecht” 1998, pp. 455-461.

62 Clearly in favour of organ donation are: E. Deutsch, A. Spickhoff, Medizinrecht. Arztrecht, Arzneimittelrecht, Medizinproduktegesetz und Transfusionsrecht [Eng. Medical Law. Physician Law, Pharmaceutical Law, Medical Devices Law and Transfusion Law], $6^{\text {th }}$ ed., Berlin 2008, No. 905, Beck Online/el. See also: P. Badura, Grundpflichten als verfassungsrechtliche Dimension [Eng. Basic Obligations as a Constitutional Dimension], "Deutsches Verwaltungsblatt" 1982, pp. 861-872.

63 B. Bozeman, Public Values and Public Interest: Counterbalancing Econimic Individualismus, Georgetown 2007 , p. 1. 
Fourthly, both the principle of reciprocity under Article 2(1) GG and the principle of equality under Article 3(1) GG are supported by the simple probability that everyone may find themselves in a situation where they will need an organ. If any of us can be a potential recipient, we can deduct from this that everyone should also be a potential donor. However, such a solution must be based on the right to individual freedom. Obligations are primarily grounded in the inaction principle ${ }^{64}$. It is difficult to derive from this a duty to take action, which is required in the opt-out model. Organ donation should be an act of goodwill, not an obligation.

Fifthly, the obligation to donate could also be based on obligations arising from human dignity contained in Article 1(1) GG. Supporters of the theory of mutual human obligations assume that the duty of the state is to ensure the inviolability of human dignity under the second sentence of Article 1(1) GG. The obligations of the state under this principle involve the protection of human dignity. They also include the duty of citizens to respect each other's dignity. They are obliged to refrain not only from acting in breach of human dignity, but also from behaving in a certain way and from tolerating certain behaviours ${ }^{65}$. A potential organ donor would violate his or her obligations towards other citizens if he or she violated the dignity of the recipient. The breach of values emphasizes the "duty of the individual (...) to respect the life of another human being" ${ }^{\prime 6}$. According to Luchterhandt, the moral duty to help other human beings becomes a legal obligation. However, he also sets limits to that, by restricting this duty to the one "who is closest to the helpless and who is capable of rendering assistance and who also fulfils it in a reasonable manner" ${ }^{167}$. Due to the anonymity of post-mortem donations, there usually is no relationship between the donor and the recipient. The human responsibilities that could result from close relationships are very different. The potential recipient would also be obliged to respect the will of the potential donor, e.g. his or her religious beliefs. Therefore, an obligation to donate cannot be based on this principle.

Sixthly, in German legal scholarship, the introduction of an opt-out-model represents a restriction of the right to self-determination (see section 4.1 above). To be constitutionally justified, a restriction of the right to self-determination in the form of an obligation to express one's opposition needs a legitimate purpose and has to respect the principle of proportionality. The protection of life or health of suffering patients on the waiting lists by increasing the number of organ donations clearly is a legitimate purpose. The conflict between the fundamental right to self-determination and the pursuit of a legitimate purpose therefore has to be solved by applying the principle of proportionality. The principle of proportionality refers to the principle of law that a certain level

${ }^{64}$ O. Luchterhandt, Grundpflichten..., p. 440; H. Hofmann, Grundpflichten als verfassungsrechtliche Dimension [Eng. Basic Obligations as a Constitutional Dimension], "Veröffentlichungen der Vereinigung der Deutschen Staatsrechtslehrer" 1983/41, pp. 43-86.

65 O. Luchterhandt, Grundpflichten..., pp. 445, 452. See also: P. Häberle, Die Menschenwürde als Grundlage der staatlichen Gemeinschaft [Eng. Human Dignity as the Basis of the State Community], in: J. Isensee, P. Kirchhof (eds.), Handbuch des Staatsrechts der Bundesrepublik Deutschland. Vol. 2. Verfassungsstaat [Eng. Handbook of the Constitutional Law of the Federal Republic of Germany. Vol. 2. Constitutional State], $3^{\text {rd }}$ ed., Heidelberg 2004, pp. 317-366; A. Zielcke, Zur Rationalität des modernen Rechts [Eng. On the Rationality of Modern Law], "Rechtstheorie” 1980/11, p. 85. Critically on inferring responsibilities from human dignity: K. Stern, Das Staatsrecht der Bundesrepublik Deutschland. Vol. 3. Allgemeine Lehren der Grundrechte. 1. Halbband [Eng. The Constitutional Law of the Federal Republic of Germany. Vol. 3. General Tenets of Fundamental Rights. $1^{\text {st }}$ Half Volume], München 1994, p. 989.

${ }_{66}$ O. Luchterhandt, Grundpflichten..., p. 444.

${ }_{67}$ O. Luchterhandt, Grundpflichten..., p. 453. 
of proportionality must be applied in the case of interference with an individual right that is considered to be permissible in the public interest ${ }^{68}$. This principle is part of the fundamental modern concept of constitutional state ${ }^{69}$. The opt-out model thus would have to be: 1) appropriate in order to achieve the intended objective; 2) necessary, i.e. there should be no less severe means of achieving the objective, and 3) - according to German legal scholarship - adequate or reasonable (German: angemessen).

1) In the legal discussion on the proposed opt-out-model, objections concerning the appropriateness of the model have been raised. According to critics, it is far from clear whether the proposed model will in fact increase the number of organ donations. A limiting factor will in any case be the small number of brain dead persons - which cannot be increased by the opt-out solution ${ }^{70}$.

2) The decision if the opt-out model is necessary requires an analysis whether alternative, less invasive but comparably effective, solutions exist. Proponents of the opt-out model have tried to show that all previous or current solutions in Germany have so far failed to significantly increase the number of donated organs. However, it remains unclear whether this failure was the result of previous or current legal solutions or rather of structural deficits inside the medical transplantation system. The legal proposal moreover failed to evaluate the most recent legal reform of the transplantation system in 2019 (see: section $1 \mathrm{fn} .5$ ). Naturally, advocates for the improved opt-in model argued that the combined effects of the 2019 reform together with their improvements would constitute a less invasive, equally effective solution.

3) Adequacy requires the measure to be proportionate to the weight and importance of the fundamental right involved ${ }^{71}$. There has to be a balance between the protected fundamental right and the conflicting public interest which requires its restriction. Intense restrictions require a particularly thorough examination. Applying this criterion, the restriction of the right to self-determination of potential organ donors in this case must be balanced with the interest of organ recipients to have a sufficient number of transplants. The proponents of the opt-out principle declare that the only burden to the citizens is to make a statement - a small duty which is easy to fulfil ${ }^{72}$. This argumentation does not go far enough, though. First of all, it should be noted that the citizen bears the risk of his or her opposition being disregarded due to an unfortunate set of circumstances. Furthermore, the opt-out solution does not only cover those who internally agree to a post-mortem donation, but have not expressly stated their will. The omission could have occurred due to completely different circumstances: either because

68 F. Hufen, Die Widerspruchslösung aus verfassungsrechtlicher Sicht [Eng: The Opt-out Solution from a Constitutional Perspective], in: J.F. Lindner (ed.), Transplantationsmedizinrecht. Beiträge zur aktuellen Diskussion um die Widerspruchslösung [Eng. Transplant Medicine Law. Contributions to the Current Discussion on the Opt-out Model], Baden-Baden 2019, p. 33.

69 A. Peters, Verhältnismäßigkeit als globales Verfassungsprinzip [Eng: Proportionality as a Global Constitutional Principle], in: B. Baade, S. Ehricht, M. Fink et al. (eds.), Verhältnismäßigkeit im Völkerrecht [Eng. Proportionality in International Law], Tübingen 2015, p. 1.

70 H. Lang, Schriftliche Stellungnahme zur Anhörung im Ausschuss für Gesundheit am 25. September 2019 [Eng. Written Opinion for the Hearing in the Committee on Health on 25 September 2019], Deutscher Bundestag, pp. 14-16, https:// tinyurl.com/y8g6sk5d, accessed on: 23 March 2020.

71 Judgment of the German Federal Constitutional Court of 20 June 1984 (1 BvR 1494/78), BVerfGE 67, pp. 157, 173.

72 H. Maurer, Die medizinische Organtransplantation in verfassungsrechtlicher Sicht [Eng. Medical Organ Transplantation from a Constitutional Perspective], "Die Öffentliche Verwaltung (DÖV)" 1980, p. 12. 
the persons concerned were never confronted with the question, or because they were disinterested or because they didn't manage to take a decision yet. Another possibility is that a person refuses an organ removal, but does not wish to disclose it $^{73}$. Nevertheless, in all these cases a non-action would have the consequence that in the event of brain death the persons concerned would automatically become potential donors and organ removal could be possible. Those grave consequences of not taking a decision - for different reasons - are not adequate to the public interest of increasing the number of transplants.

For good reasons, German law does not treat the absence of an objection as equivalent to a consent ${ }^{74}$. As already mentioned (see: section 4.3) silence usually means neither approval nor rejection but no declaration of will at all. There is no obligation to provide one's own body to third parties in the form of organ donation, as reflected by the very term organ "donation"75. The opt-out-solution creates a fiction and implies that a non-opposing person has declared something - which in reality he or she never did. Such purely implied, i.e. fictitious, consent in the core area of self-determination with regard to bodily integrity is inadmissible - especially with such serious consequences as organ removal. Therefore the proposal is not reasonable or adequate - and consequently not proportionate. Constitutionally, the restriction cannot be justified.

\section{A bill to strengthen the willingness to donate organs: the opt-in principle}

The second MPs bill promoted the opt-in model, which has been in place in Germany so far. Its aim was to introduce some improvements to the allocation system and to the structures of transplantation, seeing this as a method for increasing the citizens' readiness to donate.

It should be easier for citizens to provide evidence of their decision and to change it. The German Institute for Medical Documentation and Information (German: Deutsches Institut für Medizinische Dokumentation und Information) is working to create an online register for this purpose. It will be also possible to submit a declaration of organ donation when applying for an identity card ${ }^{76}$. Furthermore, the bill foresees a more intensive information campaign. It imposes an information obligation on general physicians, who should hold an information interview with their patients every two years, for which they can charge an additional fee refunded by the healthcare system ${ }^{77}$. Expenditure on transplant coordinators and hospitals carrying out transplantations is also assumed to increase. The solutions in this bill are based on the experience of Spain and Sweden, where priority was given to restoring citizens' confidence in the healthcare system, which in turn increased the number of people who consciously chose to donate an $\operatorname{organ}^{78}$.

The second draft followed the existing opt-in principle and argued that imposing the obligation to donate is incompatible with the German constitution and leads

73 H. Maurer, Die medizinische Organtransplantation..., p. 12.

74 H. Lang, Schriftliche Stellungnahme..., p. 20.

75 H. Lang, Schrifiche Stellungnahme..., p. 21.

76 Draft Law on the Regulation of the Double Objection in the Transplantation Law 2019, p. 3.

77 Draft Law on the Regulation of the Double Objection in the Transplantation Law 2019, p. 3.

78 W. Kluth, B. Sander, Verfassungsrechtliche Aspekte einer Organspendepflicht [Eng. Constitutional Aspects of a Duty to Donate Organs], "Deutsches Verwaltungsblatt” 1997, pp. 1285-1293. 
to violations of citizens' fundamental rights ${ }^{79}$. According to the supporters of this bill, there is no significant difference in the number of organ transplants between opt-out and opt-in countries and, in that case, why introduce another obligation for citizens that could potentially infringe their rights? ${ }^{80}$.

\title{
6. Final conclusions
}

The opt-out solution suggests the conclusion that in the event of an unresolved objection, everyone is obliged to accept a post-mortem removal of organs. In the case of an obligation to accept a post-mortem removal of organs, the individual rights of the party under such an obligation are already limited during their lifetime. Such a fundamental or solidarity obligation cannot be derived from the constitution and cannot be justified by public interest. In particular, human dignity itself cannot be used as a basis of its legitimacy. Nor can the duty of the state to protect the right to life and bodily integrity of the recipients of organs provide a justification. The restriction of the right to self-determination by imposing an obligation to express your opposition, has a legitimate purpose but does not respect the principle of proportionality.

The opt-in model seems to be more responsive to the society's needs. It does not impose an obligation on the citizens and, if other countries' experiences do not prove a statistically significant increase in the number of donors, why impose another obligation. The same outcome can be achieved through other methods that interfere with individual rights to a lesser extent.

\section{Is Post-Mortem Organ Donation a Duty Towards Society and Can It Be Justified By Public Interest? Recent Bills to Amend the German Transplantation Law}

\begin{abstract}
The issue of organ donation from deceased donors remains unsatisfactorily resolved in Germany. The number of donors has remained very low in recent years. Consequently, the German Bundestag was holding a debate on two MP bills aimed at amending the organ transplantation law. Two main bills were presented by different groups of MPs. The more controversial of them, supported by the Minister of Health, tried to introduce the opt-out model into Germany's organ transplantation system. The second one aimed to improve the existing opt-in model. During the final voting, the Bundestag decided against the opt-out model and in favour of the improved opt-in one. In some experts' eyes, an opt-out model imposes an obligation on the citizens to donate an organ after brain death. Can such a duty to the society be justified by public interest or other principles? The goal of this article is to offer an answer to this question by analysing the provisions of the German constitution.
\end{abstract}

Keywords: opt-out model, organ donation, transplants, German organ transplantation law

79 See: section 4.

80 Speech by MP Ursula Schmidt at the $106^{\text {th }}$ Session of the Bundestag on 26 June 2019, Minutes from the $106^{\text {th }}$ Session of $19^{\text {th }}$ Term of Bundestag, 26 June 2019, p. 13020, http://dipbt.bundestag.de/doc/btp/19/19106.pdf, accessed on: 27 June 2020. 


\section{BIBLIOGRAFIA / REFERENCES:}

Angstwurm, H. (2000). Der Hirntod als sicheres Todeszeichen des Menschen und als eine Voraussetzung der Organentnahme. In H. J. Firnkorn, (ed.), Hirntod als Todeskriterium. Stuttgart: Schattauer, F.K. Verlag

Alexy, R. (1996). Theorie der Grundrechte, 3rd. Ed. Frankfurt am Main: Schurkamp

Badura, P. (1982). Grundpflichten als verfassungsrechtliche Dimension, Deutsches Verwaltungsblatt, 861-872.

Bozeman, B. (2007). Public Values and Public Interest: Counterbalancing Econimic Individualismus. Georgetown: University Press

Deutsch, E., Spickhoff, A. (2008). Medizinrecht. Arztrecht, Arzneimittelrecht, Medizinproduktegesetz und Transfusionsrecht, 6th. Ed. Berlin: Springer

Häberle, P. (2004). Die Menschenwürde als Grundlage der staatlichen Gemeinschaft. In J. Isensee, P. Kirchhof, (ed.), Handbuch des Staatsrechts der Bundesrepublik Deutschland, vol. 2, Verfassungsstaat, 3rd Ed. Heidelberg: C.F. Müller

Heinrichs, H. (2011). In O. Palandt (ed.), Bürgerliches Gesetzbuch, 70th Ed. München: C.H. Beck

Heun, W. (1996). Der Hirntod als Kriterium des Todes des Menschen - Verfassungsrechtliche Grundlagen und Konsequenzen, JuristenZeitung 5, 218-236

Höfling, W. (1995). Um Leben und Tod: Transplantationsgesetzgebung und Grundrecht auf Leben, JuristenZeitung 1, 26-33

Höfling, W. (1996). Hirntodkonzeption und Transplantationsgesetzgebung, MedR Schriftenreihe Medizinrecht, 6-8

Höfling, W. (2009). Art. 1. In: M. Sachs (ed.), Grundgesetz Kommentar, 5th Ed. München: C.H. Beck

Hufen, F. (2019). Die Widerspruchslösung aus verfassungsrechtlicher Sicht. In: Joseph Franz Lindner (ed.), Transplantationsmedizinrecht. Beiträge zur aktuellen Diskussion um die Widerspruchslösung. Baden-Baden: Nomos.

Isensee, J. (1982). Die verdrängten Grundpflichten des Bürgers, Die Öffentliche Verwaltung (DÖV), 609-618.

Jarass, P. (2011). Art. 2. In: P. Bodo (ed.), Grundgesetz für die Bundesrepublik, 11 Ed. München: C.H. Beck.

Kelle, F. (2011). Eine verfassungsrechtliche Untersuchung zur Begründbarkeit einer Organspendepflicht und zur Begründbarkeit einer Organspendepflicht und zur Vereinbarkeit von Menschenwürde und Widerspruchslösung unter Berücksichtigung ethischer und medizinischer Aspekte. In H. Lilie (ed.), Schriftenreihe Medizin-Ethik-Recht. Halle (Saale): MER.

Klinge, I. (1996). Todesbegriff, Totenschutz und Verfassung. Der Tod in der Rechtsordnung unter besonderer Berücksichtigung der verfassungsrechtlichen Dimension. Baden-Baden: Nomos.

Kluth, W. (1996). Die Hirntodkonzeption: Medizinisch-anthropologische Begründung, verfassungsrechtliche Würdigung, Bedeutung für den vorgeburtlichen Würdeschutz, Zeitschrift für Lebensrecht 1, 3-10. 
Kluth, W., Sander, B. (1997). Verfassungsrechtliche Aspekte einer Organspendepflicht, Deutsches Verwaltungsblatt, 1285-1293.

Kühn, C. (1998). Das neue deutsche Transplantationsgesetz, MedR Schriftenreihe Medizinrecht, 455-461.

Liebs, D. (2007). Lateinische Rechtsregeln und Rechtssprichwörter, 7th Ed. München: C.H. Beck.

Luchterhandt, O. (1988). Grundpflichten als Verfassungsproblem in Deutschland. Geschichtliche Entwicklung und Grundpflichten unter dem Grundgesetz, Berlin: Duncker \& Humblot GmbH.

Maurer, H. (1980). Die medizinische Organtransplantation in verfassungsrechtlicher Sicht, Die Öffentliche Verwaltung (DÖV) 7, 7-15.

Mitre, C. (2017). Diagnosing "Brain Death" in Intensive Care. Journal of Critical Care Medicine 3, $128-130$

Merten, D. (1978). Grundpflichten im Verfassungssystem der Bundesrepublik Deutschland, Bayerische Verwaltungsblätter, 554-559

Nowacka, M. (2008). Filozoficzne podstawy autonomii zasady autonomii pacjenta, Problemy Higieny i Epidemiologii 3, 326-329.

Nowacka, M. (2013). Etyka transplantacji. In J .Różyńska, W. Chańska (ed.), Bioetyka. Warszawa: Wolters Kluwer.

Nowak, P.G. (2014). Problemy etyczne transplantologii. Perspektywa niedoboru narządów do przeszczepów, Diametros 42, 150-177.

Peters, A. (2019). Verhältnismäßigkeit als globales Verfassungsprinzip. In: B. Baade, S Ehricht, M. Fink et al. (eds.), Verhältnismäßigkeit im Völkerrecht. Tübingen: Mohr Siebeck.

Schachtschneider, K.A., Siebold, D. (2000). Die „erweiterte Zustimmungslösung“ des Transplantationsgesetzes im Konflikt mit dem Grundgesetz. Die Öffentliche Verwaltung (DÖV), 129-137.

Sengler, H., Schmidt, A. (1997). Verfassungsrechtliche Fragen einer gesetzlichen Regelung des Transplantationsrechts, Die Öffentliche Verwaltung (DÖV), 718-725

Siminoff, L.A., Gordon, N., Hewlett, J., Arnold, R.M. (2001). Factors influencing families' consent for donation of solid organs for transplantation, Journal of American Medical Association 1, 71-77.

Starck C. (2010). Art. 1(1). In: H. v. Mangoldt, F. Klein, C. Starck (eds.), Kommentar zum Grundgesetz, Vol. 1, 6th Ed. München: C.H. Beck

Stern, K. (1988). Das Staatsrecht der Bundesrepublik Deutschland. Vol. 3. Allgemeine Lehren der Grundrechte. 1. Halbband, München: C.H. Beck.

Rixen, S. (1999). Lebensschutz am Lebensende. Das Grundrecht auf Leben und die Hirntodkonzeption. Zugleich ein Beitrag zur Autonomie rechtlicher Begriffsbildung. Berlin: Duncker und Humblot Verlag.

Thaler, H., Sunstein, C.R. (2008). Nudge: Improving Decisions About Health, Wealth and Happiness, New Haven: Yale University Press.

Wacke, A. (1982). Keine Antwort ist auch eine Antwort. Qui tacet, consentire videtur, ubi loqui potuit ac debuit, Juristische Arbeittsblätter, 184-192.

Wagner, E., Brocker, L. (1996). Hirntodkriterium und Lebensgrundrecht, Zeitschrift für Rechtspolitik 6, $226-236$ 
Wróbel, J. (1996). Zgoda domniemana w polskiej ustawie transplantacyjnej. Wątpliwości i obawy natury etycznej. In: A. Marcol (ed.), Etyczne aspekty transplantacji narzadów, Opole: Wydział Teologiczny Uniwersytetu Opolskiego.

Zawiślak, A. (2008). Problemy autonomii osób dorosłych z niepełnosprawnością intelektualną, Rocznik Naukowy Kujawsko-Pomorskiej Szkoty Wyższej w Bydgoszczy. Transdyscyplinarne Studia o Kulturze (i) Edukacji 3, 41-46.

Zielcke, A. (1980). Zur Rationalität des modernen Rechts, Rechtstheorie 11, 85-98. 